\title{
Spectral quality as an eliciting agent in the production of phenolic compounds in the
}

\section{callus of Hyptis marrubioides Epling}

\author{
Qualidade espectral como agente eliciador na produção de compostos fenólicos em calo de Hyptis
} marrubioides Epling

Calidad espectral como agente inductor en la producción de compuestos fenólicos en el callo de Hyptis marrubioides Epling

Luciana Arantes Dantas

ORCID: https://orcid.org/0000-0001-8138-4824 Instituto Federal de Educação, Ciência e Tecnologia Goiano, Brasil

E-mail: dra.luciana@hotmail.com

Paula Sperotto Alberto Faria

ORCID: https://orcid.org/0000-0002-1933-3759 Instituto Federal de Educação, Ciência e Tecnologia Goiano, Brasil

E-mail: paulasperotto@gmail.com

Anielly Monteiro de Melo

ORCID: https://orcid.org/0000-0003-1327-3633 Instituto Federal de Educação, Ciência e Tecnologia Goiano, Brasil E-mail: anielly_@hotmail.com

Márcio Rosa

ORCID: https://orcid.org/0000-0003-0893-8178

Universidade de Rio Verde, Brasil

E-mail:marciorosa@unirv.edu.br

Erika Crispim Resende

ORCID: https://orcid.org/0000-0003-2388-9079 Instituto Federal de Educação, Ciência e Tecnologia Goiano, Brasil E-mail: erika.resende@ifgoiano.edu.br

Paulo Sérgio Pereira

ORCID: https://orcid.org/0000-0002-0155-8968 Instituto Federal de Educação, Ciência e Tecnologia Goiano, Brasil E-mail: paulo.pereira@ifgoiano.edu.br

Fabiano Guimarães Silva

ORCID: https://orcid.org/0000-0003-4908-2265 Instituto Federal de Educação, Ciência e Tecnologia Goiano, Brasil E-mail: fabiano.silva@ifgoiano.edu.br

Aurélio Rubio Neto

ORCID: https://orcid.org/0000-0003-0517-1223 Instituto Federal de Educação, Ciência e Tecnologia Goiano, Brasil E-mail: aurelio.rubio@ifgoiano.edu.br

\begin{abstract}
Hyptis marrubioides Epling is a species of the Brazilian cerrado traditionally used to treat gastrointestinal and cutaneous infections, pain, and cramps. The use of visible and ultraviolet $\mathrm{C}$ (UVC) radiation is a promising strategy to optimize the production of the bioactive metabolites. Therefore, the effect of the spectral quality of light on the production of metabolites was evaluated in $H$. marrubioides callus. The callus was inoculated on MS medium with $50 \%$ of the salt concentration containing $2 \mathrm{mg} \mathrm{L}^{-1}$ naphthaleneacetic acid (NAA) and $1 \mathrm{mg} \mathrm{L}^{-1}$ benzylaminopurine (BAP). The callus cultures were exposed for 20 days to the spectral qualities of white light, blue, red, and blue + red as well as to darkness. In addition, the callus cultivated under white light were exposed to UVC on the 21st day for 0, $30,60,120$, and 240 seconds. The exposure of $H$. marrubioides callus to blue light negatively affects the synthesis of phenolic compounds. Red light stimulates the synthesis of caffeic acid and luteolin. Darkness was the best condition among those studied because it was associated with the increased accumulation of caffeic acid, chlorogenic acid, rosmarinic acid, and luteolin. The exposure of H. marrubioides callus cultivated under white light to UVC radiation promoted an increase in the synthesis of chlorogenic acid, ferulic acid, rosmarinic acid, and luteolin.
\end{abstract}

Keywords: Abiotic elicitation; Callus culture; HPLC; Light quality; UVC radiation. 


\begin{abstract}
Resumo
Hyptis marrubioides Epling é uma espécie do cerrado brasileiro tradicionalmente utilizada no tratamento de infecções gastrointestinais e cutâneas, dores e cólicas. O uso de radiação visível e ultravioleta C (UVC) é uma estratégia promissora para otimizar a produção dos metabólitos bioativos. Portanto, o efeito da qualidade espectral da luz sobre a produção de metabólitos foi avaliado em calos de H. marrubioides. O calo foi inoculado em meio MS com 50\% da concentração de sal contendo $2 \mathrm{mg} \mathrm{L}^{-1}$ de ácido naftaleno acético (ANA) e $1 \mathrm{mg} \mathrm{L}^{-1}$ de benzilaminopurina (BAP). As culturas de calos foram expostas por 20 dias às qualidades espectrais da luz branca, azul, vermelha e azul + vermelha, bem como à escuridão. Além disso, os calos cultivados sob luz branca foram expostos à UVC no $21^{\circ}$ dia por $0,30,60$, 120 e 240 segundos. A exposição do calo de $H$. marrubioides à luz azul afeta negativamente a síntese de compostos fenólicos. A luz vermelha estimula a síntese de ácido cafeico e luteolina. A escuridão foi a melhor condição entre as estudadas porque estava associada ao aumento do acúmulo de ácido cafeico, ácido clorogênico, ácido rosmarínico e luteolina. A exposição de calos de $H$. marrubioides cultivados sob luz branca à radiação UVC promoveu aumento na síntese de ácido clorogênico, ácido ferúlico, ácido rosmarínico e luteolina.
\end{abstract}

Palavras-chave: Elicitação abiótica; Cultura de calos, HPLC, Qualidade da luz, Radiação UVC.

\title{
Resumen
}

Hyptis marrubioides Epling es una especie del cerrado brasileño utilizada tradicionalmente para tratar infecciones gastrointestinales y cutáneas, dolores y calambres. El uso de la radiación C (UVC) visible y ultravioleta es una estrategia prometedora para optimizar la producción de metabolitos bioactivos. Por lo tanto, se evaluó el efecto de la calidad espectral de la luz sobre la producción de metabolitos en callos de H. marrubioides. Se inoculó ele callo en medio MS con 50\% de la concentración de sal que contenía $2 \mathrm{mg} \mathrm{L}-1$ de ácido naftalenacético (NAA) y $1 \mathrm{mg} \mathrm{L}-1$ de bencilaminopurina (BAP). Se expusieron por 20 días, los cultivos de los callos a las cualidades espectrales de luz blanca, azul, rojo y azul + rojo, así como a la oscuridad. Además, el callo cultivado bajo luz blanca se expuso a UVC el día 21 durante $0,30,60,120$ y 240 segundos. La exposición del callo de $H$. marrubioides a la luz azul, afecta negativamente la síntesis de compuestos fenólicos. La luz roja estimula la síntesis de ácido cafeico y luteolina. La mejor condición entre los estudiados, fue en la oscuridad porque se asoció con una mayor acumulación de ácido cafeico, ácido clorogénico, ácido rosmarínico y luteolina. La exposición del callo de H. marrubioides cultivado bajo luz blanca a la radiación UVC promovió un aumento en la síntesis de ácido clorogénico, ácido ferúlico, ácido rosmarínico y luteolina.

Palabras clave: Elicitación abiótica; Cultivo de callos; HPLC; Calidad de la luz; Radiación UVC.

\section{Introduction}

Hyptis marrubioides Epling, popularly known as "hortelã-do-campo" ("field mint"), is considered a medicinal species found in the Brazilian cerrado that is traditionally used to treat cramps as well as gastrointestinal and cutaneous infections (Rodrigues and Carvalho, 2001). Records exist regarding the occurrence of an extreme diversity of the Hyptis species in the Brazilian cerrado, several of which have medicinal properties of pharmaceutical relevance (Arrigoni-Blank et al., 2008; Coutinho et al., 2009).

Antimicrobial, cytotoxic, and insecticidal effects are attributed to this genus given the variety of its bioactive constituents (Kuhnt et al., 1995). Previous studies have demonstrated its relevant biological activities such as its antispasmodic, anti-inflammatory, antiulcerogenic (Barbosa and Ramos, 1992), larvicidal (Costa et al., 2005), and antidepressant (Bueno et al., 2006) effects.

Several chemical, physical, and biological factors are responsible for stimulating the production of the bioactive compounds in plants (Murthy et al., 2014). The plant tissue culture technique enables researchers to control the factors that affect the biosynthesis of a given bioactive compound (Ramakrishna and Ravishankar, 2011). In an aseptic environment, adjustments in temperature, radiation, osmosis, nutrients, growth regulators, photoperiod, and the cultivation of plant material (seedlings, callus, cell suspension, and transformed roots) are performed to extract the bioactive compound throughout the year without environmental or economic loss (Villacís-Chiriboga et al., 2020).

Light quality affects the biosynthesis of secondary metabolites and can increase or decrease their accumulation (Coelho et al., 2007) because it regulates a sophisticated system of photoreceptors, and this regulation assists plant adaptation to several environmental conditions. This system includes cryptochromes and phytochromes, which are related to the 
absorption of blue and red light, respectively, and are responsible for several physiologic responses as well as the regulation of the metabolism of phenolic compounds such as anthocyanins (Liu et al., 2015).

The use of different spectral qualities was verified in Stevia rebaudiana Bert. callus as a promising method to improve the production of antioxidant metabolites. Specifically, blue light was shown to favor the production of phenolic and flavonoid compounds (Ahmad et al., 2016). Light acts on plants by providing energy through photosynthesis; however, it also plays an important role in regulating plant growth and differentiation (Wang et al., 2001). Certain wavelengths exert specific responses in plants. Blue light $(400-500 \mathrm{~nm})$ is responsible for controlling phototropism, leaf expansion, stem growth, and anthocyanin accumulation. Red light $(660 \mathrm{~nm})$ controls germination as well as stem and petiole growth. Both wavelengths affect flowering and gene expression (Carvalho and Folta, 2014).

Exposure to ultraviolet (UV) radiation exerts a powerful stressor on plants, and this effect can be observed in callus cultures as a decrease in growth and differential metabolic modulation (Zagoskina et al., 2003). UV radiation seems to act primarily on the synthesis of phenolic compounds, given that this metabolic class plays an important role in overcoming oxidative stress (Hernandez-Aguilar et al., 2021). Therefore, the cell's capacity for the formation of phenolic compounds is directly proportional to its resistance to UV radiation (Dias et al., 2016; Huché-Thélier et al., 2016). Important metabolic alterations were observed following ultraviolet C (UVC) treatment of the leaves of Cissus antarctica Vent., Vitis vinifera L., and Cannabis sativa L., resulting in a higher accumulation of phenylpropanoids and stilbenes, in addition to an increase in antioxidant activity in the extracts of $V$. vinifera (Marti et al., 2014).

Considering the variation in the concentration of phenolic compounds as a function of abiotic factors as well as the widespread biotechnological application of these compounds, this study sought to quantify the synthesis of these compounds in callus cultures of $H$. marrubioides exposed to different spectral qualities.

\section{Methodology}

In vitro cultivation was performed at the Laboratory of Plant Tissue Culture of the Federal Institute of Education, Science and Technology Goiano (IF Goiano), Rio Verde Campus, and the phytochemical evaluations were performed at the Laboratory of Chemistry of the Federal Institute of Education, Science and Technology Goiano, Iporá Campus. The scientific method used in this work was a quantitative and qualitative laboratory research, with the application of statistic methods to analyze the collected data (Pereira et al., 2018).

\subsection{Establishment of callus}

The culture of H. marrubioides callus was obtained from leaf segments inoculated in 250-mL flasks containing $40 \mathrm{~mL}$ of Murashige and Skoog (MS) medium (Murashige and Skoog, 1962) with half of the original concentration of salts, supplemented with $30 \mathrm{~g} \mathrm{~L}^{-1}$ sucrose, $2 \mathrm{mg} \mathrm{L}^{-1}$ naphthaleneacetic acid (NAA) (Sigma), $1 \mathrm{mg} \mathrm{L}^{-1}$ 6-benzylaminopurine (BAP) (Sigma), and $3.5 \mathrm{~g} \mathrm{~L}^{-1}$ agar (Dinâmica ${ }^{\circledR}$ ). After inoculation, the cultures remained in a growth room under a photoperiod of 16 hours, with photosynthetically active radiation of $45-55 \mu \mathrm{mol} \mathrm{m} \mathrm{m}^{-2} \mathrm{~s}^{-1}$, and at a temperature of $25 \pm 3^{\circ} \mathrm{C}$, with subcultivation performed every 30 days.

\subsection{Light elicitation}

\subsubsection{Exposure to different spectral ranges}

Cultures with already established callus were cultivated for 20 days in the same medium used during establishment, under the following spectral ranges: white light $(400-700 \mathrm{~nm})$, blue light $(400-450 \mathrm{~nm})$, red light $(600-700 \mathrm{~nm})$, blue/red light, 
and darkness (Figure 1). The spectral composition was determined with a spectroradiometer (model USB2000, Ocean Optics, Dunedin, FL, USA).

Figure 1. Spectral ranges obtained from fluorescent lamps using (A) white, (B) blue, (C) red, or (D) blue + red light, with an irradiance of $50 \mu \mathrm{mol} \mathrm{m} \mathrm{m}^{-2} \mathrm{~s}^{-1}$.

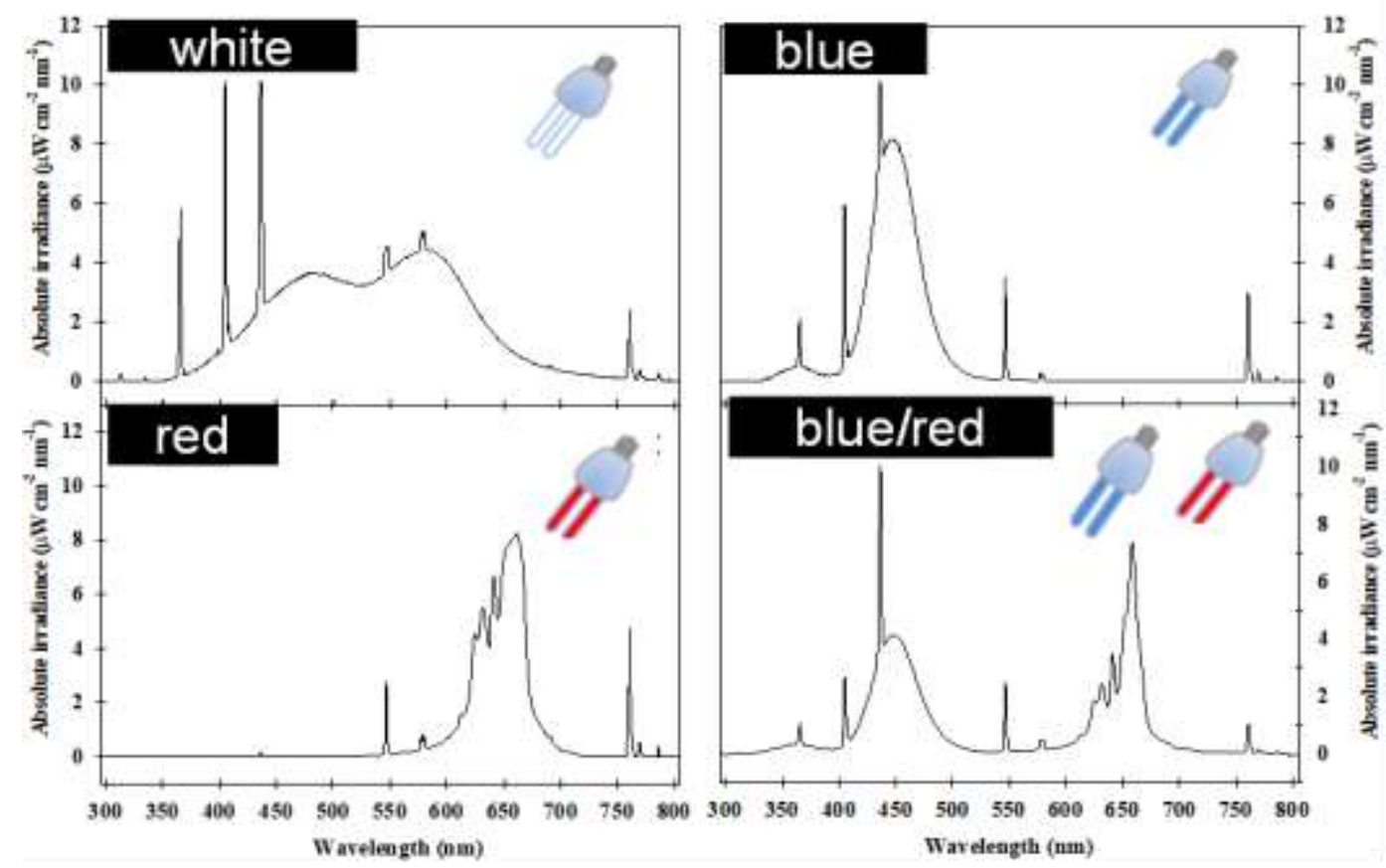

Source: Authors (2021).

The experimental design was completely randomized, with five spectral ranges (white light, blue light, red light, blue/red light, and darkness); each treatment had 10 repetitions. Quantitative data were evaluated using an analysis of variance (ANOVA) via the F-test (5\%), whereas qualitative data were analyzed using the Tukey test via SISVAR (Ferreira, 2011).

\subsubsection{Exposure to $U V C$ radiation}

To investigate the effect of UVC radiation on the production of the phenolic compounds in H. marrubioides callus, cultures of callus cultivated under white light were exposed to light from a UVC lamp (Philips TUV - $6 \mathrm{~W}$, wavelength $=$ $253.7 \mathrm{~nm}$ ) (Figure 2) on the $21^{\text {st }}$ day of cultivation inside a laminar flow hood after removing the lid of the cultivation flask for 0, 30, 60, 120, and 240 seconds. The callus were collected for analysis 24 and 48 hours after exposure. 
Figure 2. The distribution of the spectra obtained using the UVC lamp.

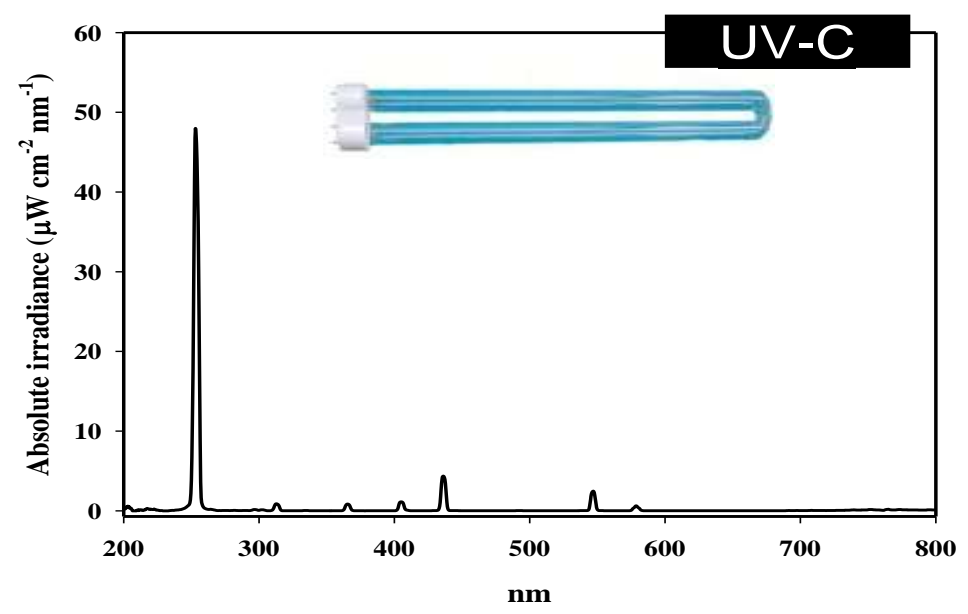

Source: Authors (2021).

The experimental design was completely randomized, with a factorial arrangement of 5 x 2 (five UV exposures and two collection times); each treatment had 12 repetitions. The quantitative data were evaluated using an ANOVA via the F-test $(5 \%)$ or a regression, whereas the qualitative data were analyzed using the Tukey test via SISVAR (Ferreira, 2011).

\subsection{Biometric evaluations}

After exposure to the eliciting agents, the callus cultures were removed from the flasks and immediately weighed to obtain the fresh weight value. Then, the cultures were dried in a hot ventilation oven at $35^{\circ} \mathrm{C}$ for 48 hours and later weighed to the obtain dry weight value.

\subsection{Phytochemical evaluations}

Extracts were prepared using $0.2 \mathrm{~g}$ of dry weight of callus with $5 \mathrm{~mL}$ of methanol for high-performance liquid chromatography (HPLC; neon) in an ultrasonic bath for 30 minutes. Next, filtration with a cotton and membrane filter (Advantec HP020AN, $20 \mu \mathrm{m}$ ) was performed. A chromatographic analysis was performed using HPLC Shimadzu, with photodiode detector with deuterium and tungsten lamp $(\lambda=254 \mathrm{~nm})$, model SPD-M20A, and an LC18 column $(25 \mathrm{~cm} \times 4.6$ $\mathrm{mm}, 5 \mu \mathrm{m}$, Supelcosil ${ }^{\mathrm{TM}}$ ) attached to the pre-column LC18, $2 \mathrm{~cm}$ (Supelguard, Supelco), with the oven set to $30^{\circ} \mathrm{C}$.

The amount $20 \mu \mathrm{L}$ of the extracts was injected in triplicate, and the phenolic compounds were detected at $254 \mathrm{~nm}$. The elution flow rate was adjusted to $1 \mathrm{~mL} / \mathrm{min}$, with mobile phase A of $0.1 \%$ acetic acid and mobile phase $\mathrm{B}$ of methanol for HPLC (neon). The program was adjusted to an increasing gradient of elution during the mobile phase B, from $10 \%$ to $66 \%$ in 32 minutes, decreasing from $66 \%$ to $10 \%$ in 32 to 35 minutes and an isocratic mode at $10 \%$ for 5 minutes, with a total run time of 40 minutes.

The detection of the compounds present in the samples was performed by comparing the peaks of the standard solutions of known phenolic acids, and quantification was performed by equating the following standard solutions: gallic acid, epicatechin, caffeic acid, chlorogenic acid, ferulic acid, orientin, vitexin, rosmarinic acid, myricetin, isovitexin, hesperidin, rutin, quercetin-3-glucoside, kaempferol-3-galactoside, quercetin, kaempferol-3-glucoside, quercetin, kaempferol, luteolin, and apigenin. 


\section{Results}

\subsection{Exposure to different spectral ranges}

The exposure of $H$. marrubioides callus to different spectral qualities did not promote variation in morphological aspects, except for those exposed to darkness (Figure 3-E). All calluses were classified as friable.

Figure 3. The morphological aspects of $\mathrm{H}$. marrubioides callus cultivated with fluorescent lamps under (A) white light; (B) blue light; (C) blue + red light; (D) red light; and (E) darkness); Bar = 0,5 cm.

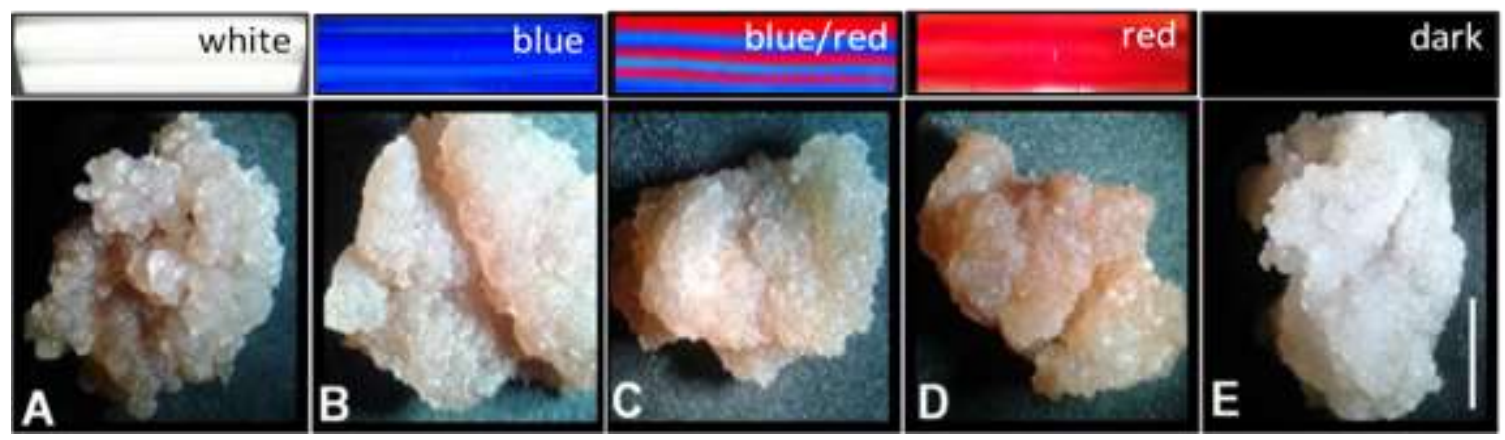

Source: Authors (2021).

The callus cultivated under blue + red light (16.90 g) showed higher fresh weight than those cultivated under red light (14.31 g) or in darkness (12.83 g; Figure 4-A). However, no variation was found in the dry weight of the different cultures (Figure 4-B).

Figure 4. The fresh (A) and dry (B) weights of $H$. marrubioides callus cultivated under an irradiance of $50 \mu \mathrm{mol} \mathrm{m} \mathrm{m}^{-2} \mathrm{~s}^{-1}$ after exposure to white light, blue light, red light, blue + red light, or darkness. Means were compared using the Tukey test. Bars indicate the standard error of the mean, and $*$ denotes no significant difference $(\mathrm{p}<0.05)$.
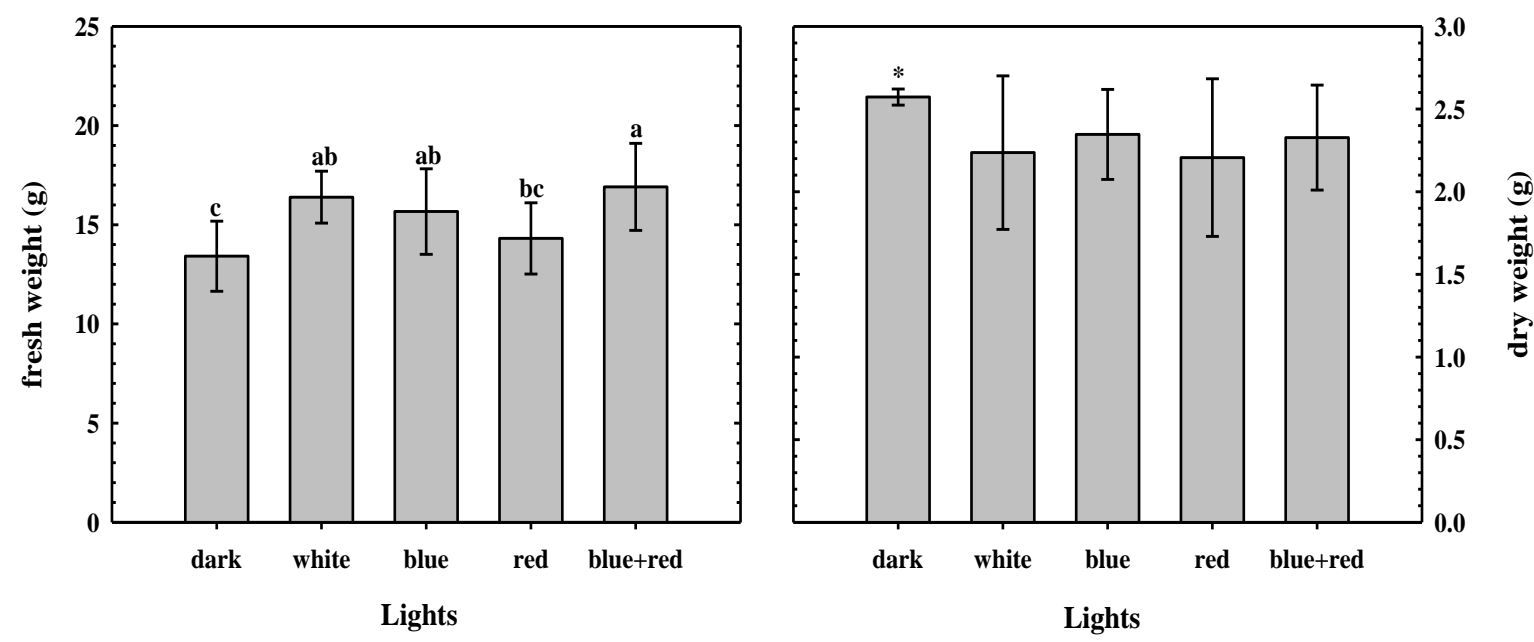

Source: Authors (2021).

During the elicitation process of this study, the following compounds were not detected: epicatechin, orientin, myricetin, isovitexin, hesperidin, rutin, quercetin-3-glucoside, vitexin, kaempferol-3-glucoside, and apigenin. The compounds gallic acid, quercetin, and kaempferol were detected; however, they did not vary as a function of the different elicitation environments. Figure 5 shows the spectra obtained from the metabolites (caffeic acid, chlorogenic acid, ferulic acid, rosmarinic acid, and luteolin) that were affected by the light qualities in terms of content, yield, or both. 
Figure 5. Spectra obtained using an HPLC-diode array detector (DAD) of phenolic compounds with oscillating behavior produced by $H$. marrubioides callus cultivated under different spectral qualities.
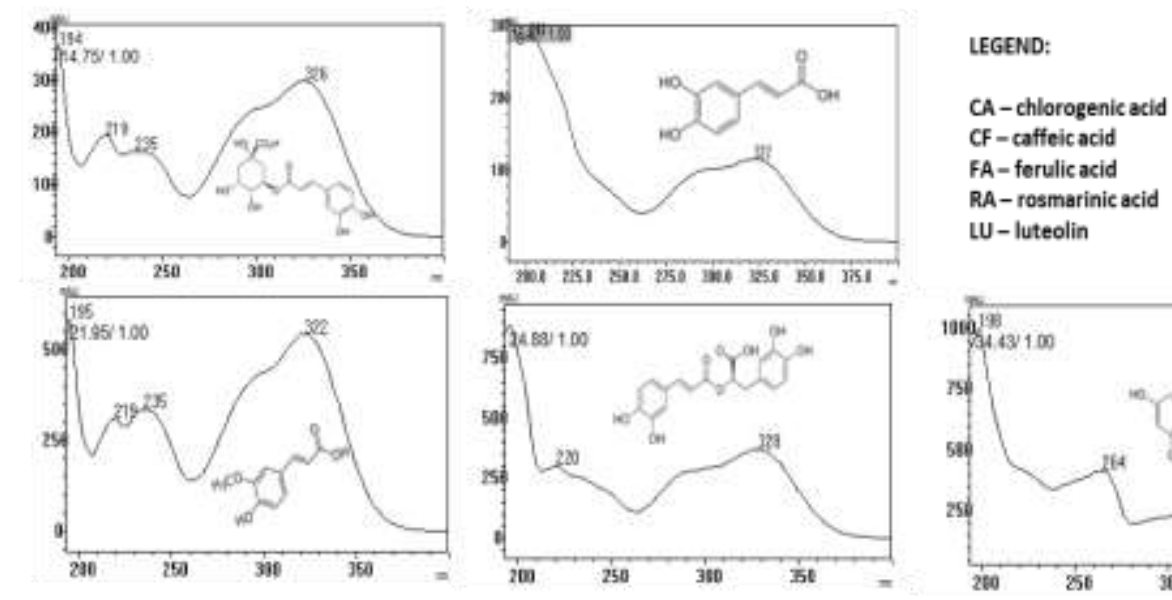

LEGEND:

CA - chlorogenic acid

CF-caffeic acid

FA- ferulic acid

RA- rosmarinic acid

LU- luteolin
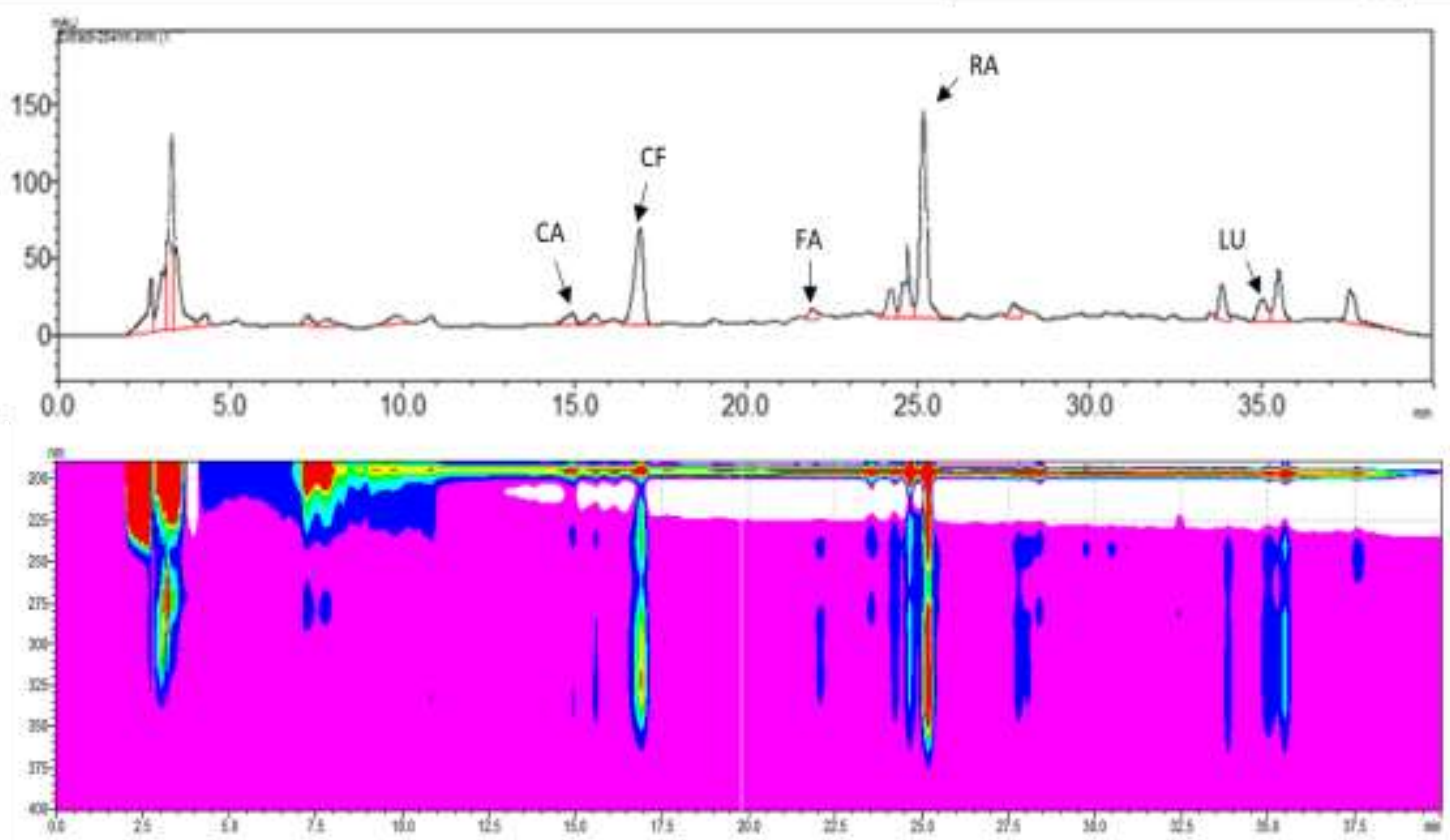

Source: Authors (2021).

The highest contents and yields of caffeic acid occurred in the callus cultivated under red light $\left(0.241 \mathrm{mg} \mathrm{g}^{-1}\right.$ and $0.5324 \mathrm{mg} / \mathrm{flask}$, respectively) and those under darkness (0.283 $\mathrm{mg} \mathrm{g}^{-1} 0.7022 \mathrm{mg} / \mathrm{flask}$, respectively; Figure 6-A and B). The remaining treatments showed no difference. Chlorogenic acid was detected only in darkness (Figure 6-C), reaching a content of $0.016 \mathrm{mg} \mathrm{g}^{-1}$ and a yield of $0.0404 \mathrm{mg} / \mathrm{flask}$ (Figure 6-D).

The content of rosmarinic acid was higher in the callus cultivated under darkness $\left(1.9082 \mathrm{mg} \mathrm{g}^{-1}\right)$, blue + red light (1.7462 $\left.\mathrm{mg} \mathrm{g}^{-1}\right)$, or white light $\left(1.7172 \mathrm{mg} \mathrm{g}^{-1}\right)$ (Figure 6-E); the results for red light $\left(1.1856 \mathrm{mg} \mathrm{g}^{-1}\right.$ ) were similar, whereas the content under blue light $\left(0.5808 \mathrm{mg} \mathrm{g}^{-1}\right)$ was the lowest. The highest yields (Figure 6-F) of this metabolite were obtained with regard to the callus cultivated under darkness $(4.7228 \mathrm{mg} / \mathrm{flask})$, white light $(3.8396 \mathrm{mg} / \mathrm{flask})$, or blue + red light $(4.1508$ $\mathrm{mg} / \mathrm{flask})$, followed by those cultivated under blue light ( $1.3627 \mathrm{mg} / \mathrm{flask})$ or red light ( $2.6155 \mathrm{mg} / \mathrm{flask})$, which did not differ.

Similar to caffeic acid, the highest contents and yields of luteolin occurred with regard to the callus cultivated under red light $\left(0.6352 \mathrm{mg} \mathrm{g}^{-1}\right.$ and $1.4014 \mathrm{mg} / \mathrm{flask}$, respectively) and under darkness $\left(0.4163 \mathrm{mg} \mathrm{g}^{-1}\right.$ and $1.0305 \mathrm{mg} / \mathrm{flask}$, respectively) (Figure 6-G and $\mathrm{H}$ ). The remaining treatments showed no difference. 

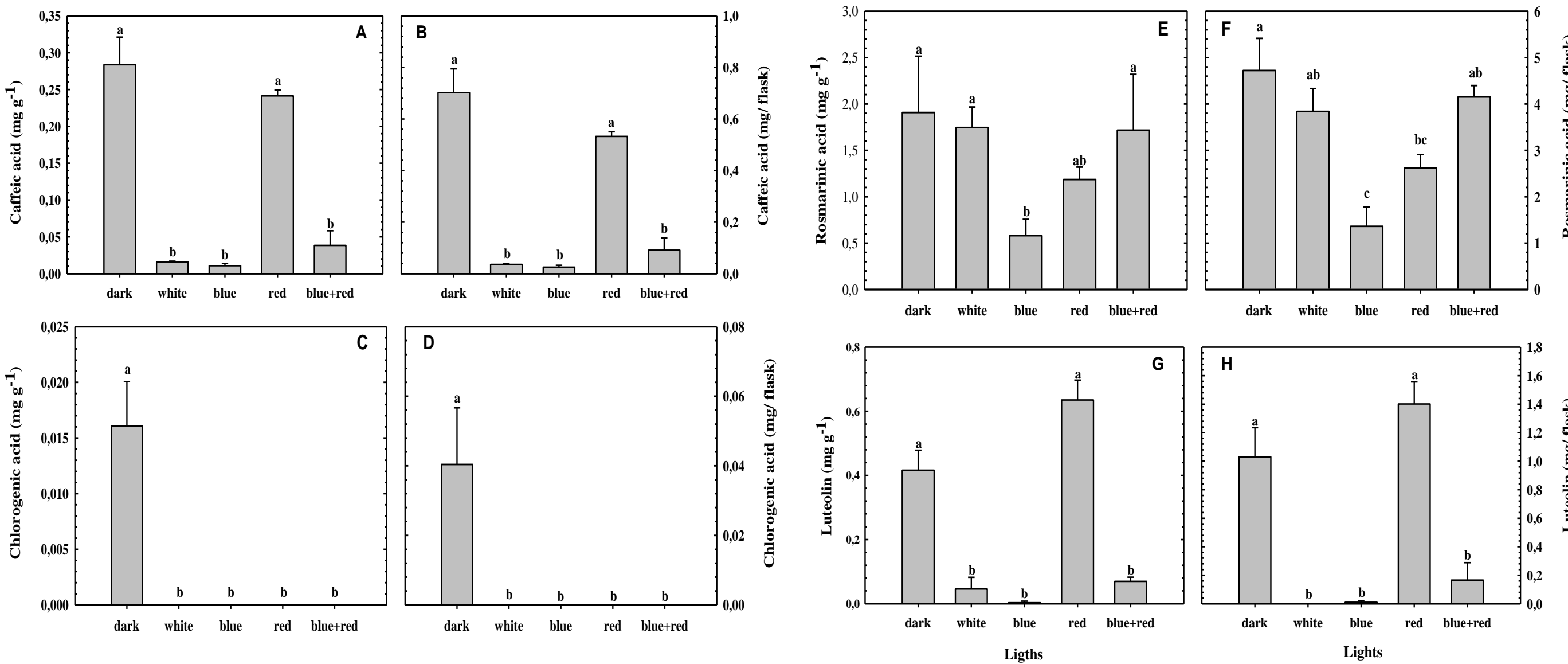

Figure 6. Content and yield, respectively: caffeic acid ( $\mathrm{A}$ and $\mathrm{B})$, chlorogenic acid ( $\mathrm{C}$ and $\mathrm{D})$, rosmarinic acid $(\mathrm{E}$ and $\mathrm{F})$ and luteolin $(\mathrm{G}$ and $\mathrm{H})$ in H. marrubioides callus cultivated under an irradiance of $50 \mu \mathrm{mol} \mathrm{m} \mathrm{m}^{-2} \mathrm{~s}^{-1}$ with different spectral qualities (i.e., white, blue, red, and blue + red) and under darkness. Means were compared across disparate exposures, and unique letters indicate significant differences in the means $(\mathrm{p}<0.05)$. Bars indicate the standard error of the mean. Source: Authors $(2021)$. 
In Cyclopia subternada Vogel callus, blue light was the best condition regarding the production of hesperidin (Kokotkiewicz et al., 2014). However, hesperidin was not detected in any of the light conditions tested in this study. Satisfactory responses were found in Prunella vulgaris L. callus during the processes of the biomass accumulation and production of bioactive compounds when different light qualities were applied; furthermore, blue light efficiently increased the production of phenolic compounds (Fazal et al., 2016). A similar result occurred with regard to S. rebaudiana (Ahmad et al., 2016). The behavior of these two species contrasts with that of $H$. marrubioides observed in this study. This contrast confirms the observations of Tariq and colleagues (Tariq et al., 2014) regarding the variabilities in biochemical and physiological responses, which was also attributed to the study species.

\subsection{Exposure to UVC radiation}

Under the conditions tested in this study, exposure to UVC radiation did not affect the accumulation of the fresh weight callus culture of $\mathrm{H}$. marrubioides. By contrast, the accumulation of dry weight showed a quadratic behavior, with maximum accumulation after 120 seconds of UVC exposure (Figure 7).

Figure 7. Dry weight (g) of $H$. marrubioides callus exposed to $0,30,60,120$, or 240 seconds of UVC radiation. Data are composed of means of $n=10$. Significance: $* p<0.05$.

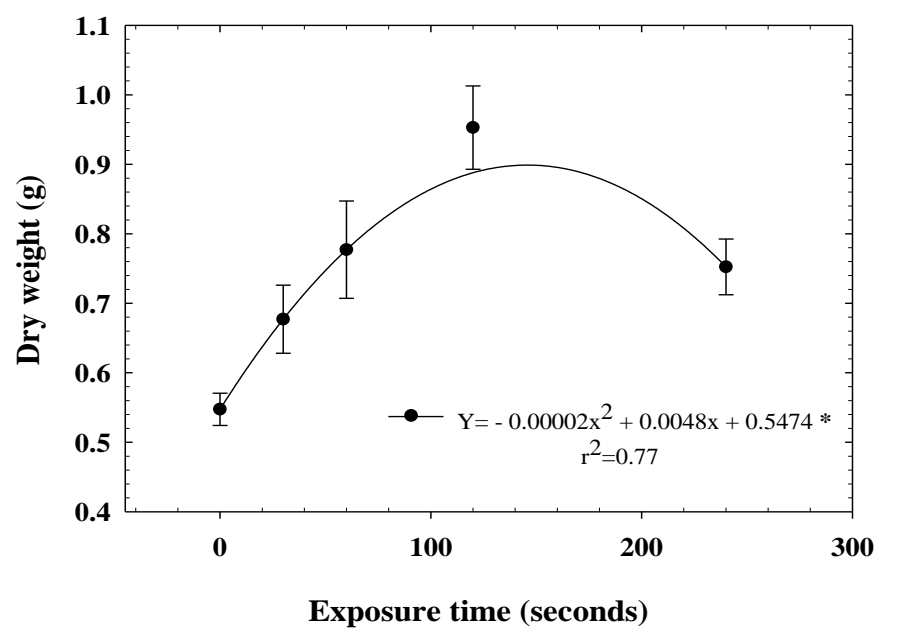

Source: Authors (2021).

In this study, after exposure to UVC radiation, the presences of phenolic compounds such as chlorogenic acid, caffeic acid, ferulic acid, rosmarinic acid, and luteolin were detected, with respective retention times of 14.4, 16.8, 21.9, 25.1, and 34.3 minutes. Of these compounds, chlorogenic acid, rosmarinic acid, and luteolin had the highest accumulation 48 hours after exposure to UVC radiation. The same behavior was observed in terms of yield, except for rosmarinic acid, which did not show variation after exposure. Both the content and yield of ferulic acid were higher 24 hours after UVC exposure. Although the content of caffeic acid did not vary, a higher yield per flask was observed 24 hours after UVC exposure (Figure 8). 

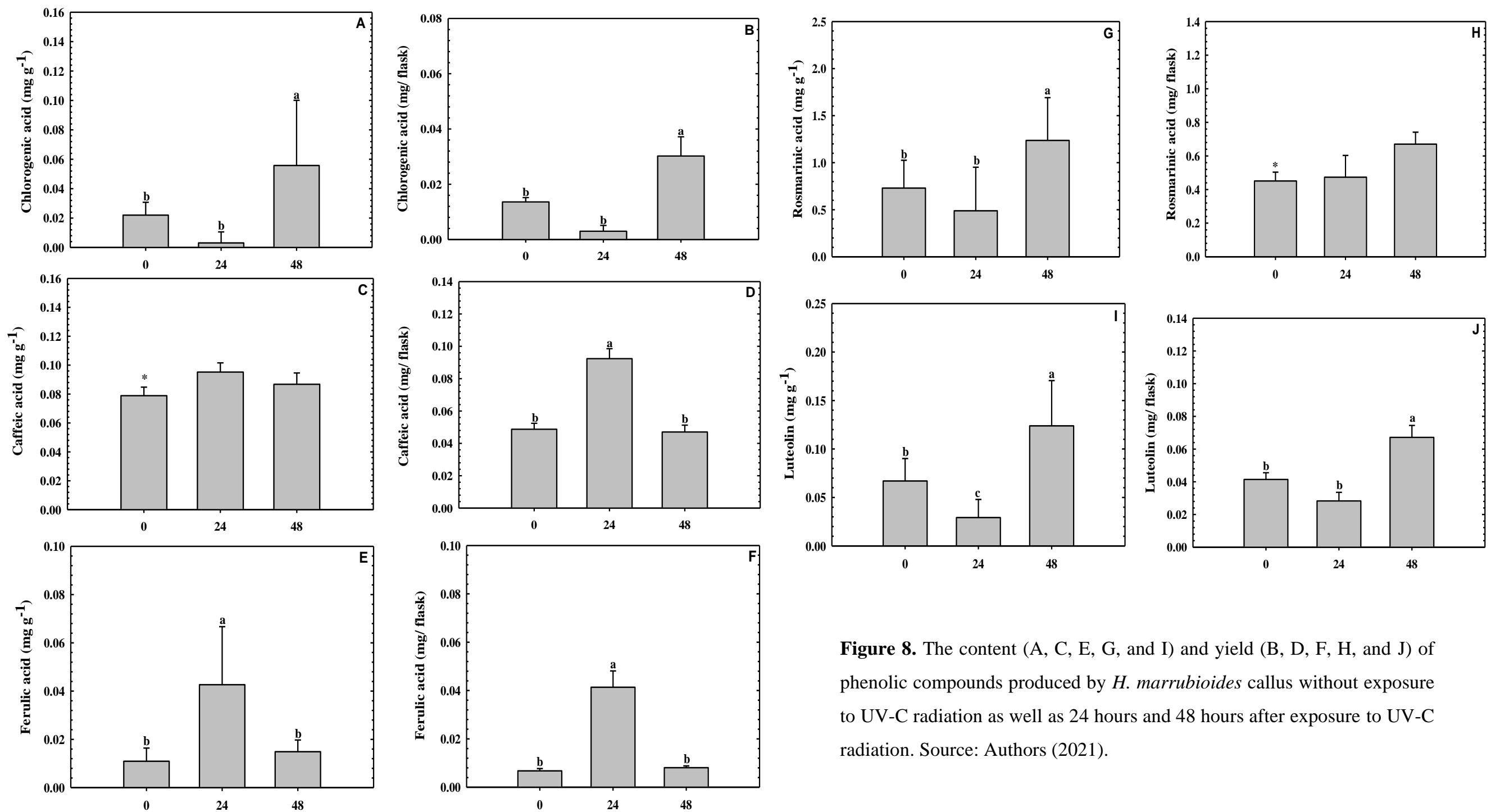

Figure 8. The content (A, C, E, G, and I) and yield (B, D, F, H, and J) of phenolic compounds produced by $H$. marrubioides callus without exposure to UV-C radiation as well as 24 hours and 48 hours after exposure to UV-C radiation. Source: Authors (2021). 
Time of exposure to UVC radiation did not increase the content or yield of chlorogenic acid, caffeic acid, rosmarinic acid, or luteolin. However, callus subjected to UVC radiation for 30 seconds showed a higher content and yield of ferulic acid (Table 1).

Table 1. The content and yield of chlorogenic acid, caffeic acid, ferulic acid, rosmarinic acid, and luteolin in $H$. marrubioides callus exposed to UVC radiation for $0,30,60,120$, and 240 seconds.

\begin{tabular}{|c|c|c|c|c|c|}
\hline $\begin{array}{l}\text { Time of } \\
\text { exposure } \\
\text { (seconds) }\end{array}$ & $\begin{array}{l}\text { Chlorogenic } \\
\text { acid }\end{array}$ & Caffeic acid & Ferulic acid & Rosmarinic acid & Luteolin \\
\hline
\end{tabular}

\section{Content of phenolic compounds ( $\left.\mathrm{mg} \mathrm{g}^{-1}\right)$}

\begin{tabular}{cccccc}
\hline $\mathbf{0}$ & $0.0220^{\mathrm{a}} \pm 0.002$ & $0.0789^{\mathrm{a}} \pm 0.003$ & $0.0109^{\mathrm{c}} \pm 0.001$ & $0.7299^{\mathrm{ab}} \pm 0.107$ & $0.0670^{\mathrm{a}} \pm 0.003$ \\
$\mathbf{3 0}$ & $0.0266^{\mathrm{a}} \pm 0.017$ & $0.1069^{\mathrm{a}} \pm 0.009$ & $0.0476^{\mathrm{a}} \pm 0.002$ & $1.2652^{\mathrm{a}} \pm 0.204$ & $0.0816^{\mathrm{a}} \pm 0.017$ \\
$\mathbf{6 0}$ & $0.0203^{\mathrm{a}} \pm 0.005$ & $0.0738^{\mathrm{a}} \pm 0.008$ & $0.0228^{\mathrm{bc}} \pm 0.005$ & $0.6052^{\mathrm{b}} \pm 0.054$ & $0.0737^{\mathrm{a}} \pm 0.003$ \\
$\mathbf{1 2 0}$ & $0.0485^{\mathrm{a}} \pm 0.016$ & $0.0845^{\mathrm{a}} \pm 0.017$ & $0.0281^{\mathrm{b}} \pm 0.002$ & $0.6091^{\mathrm{b}} \pm 0.093$ & $0.0897^{\mathrm{a}} \pm 0.018$ \\
$\mathbf{2 4 0}$ & $0.0223^{\mathrm{a}} \pm 0.004$ & $0.0988^{\mathrm{a}} \pm 0.007$ & $0.0167 \mathrm{~b}^{\mathrm{c}} \pm 0.001$ & $0.9700^{\mathrm{ab}} \pm 0.072$ & $0.0611^{\mathrm{a}} \pm 0.006$ \\
\hline
\end{tabular}

\section{Yield of phenolic compounds (mg/flask)}

\begin{tabular}{cccccc}
\hline $\mathbf{0}$ & $0.0133^{\mathrm{a}} \pm 0.001$ & $0.0494^{\mathrm{a}} \pm 0.002$ & $0.0067^{\mathrm{c}} \pm 0.001$ & $0.4463^{\mathrm{ab}} \pm 0.060$ & $0.0407^{\mathrm{ab}} \pm 0.001$ \\
$\mathbf{3 0}$ & $0.0133^{\mathrm{a}} \pm 0.008$ & $0.0643^{\mathrm{a}} \pm 0.004$ & $0.0313^{\mathrm{ab}} \pm 0.001$ & $0.7498^{\mathrm{a}} \pm 0.107$ & $0.0460^{\mathrm{ab}} \pm 0.008$ \\
$\mathbf{6 0}$ & $0.0119^{\mathrm{a}} \pm 0.003$ & $0.0546^{\mathrm{a}} \pm 0.005$ & $0.0182^{\mathrm{bc}} \pm 0.004$ & $0.3772^{\mathrm{b}} \pm 0.039$ & $0.0492^{\mathrm{ab}} \pm 0.003$ \\
$\mathbf{1 2 0}$ & $0.0270^{\mathrm{a}} \pm 0.008$ & $0.0818^{\mathrm{a}} \pm 0.015$ & $0.0324^{\mathrm{a}} \pm 0.003$ & $0.4354^{\mathrm{ab}} \pm 0.089$ & $0.0670^{\mathrm{a}} \pm 0.007$ \\
$\mathbf{2 4 0}$ & $0.0143^{\mathrm{a}} \pm 0.003$ & $0.0757^{\mathrm{a}} \pm 0.005$ & $0.0129^{\mathrm{c}} \pm 0.001$ & $0.5922^{\mathrm{ab}} \pm 0.041$ & $0.0339^{\mathrm{b}} \pm 0.001$ \\
\hline
\end{tabular}

\footnotetext{
${ }^{1}$ Means followed by the same letter in a column do not differ according to the Tukey test with a 5\% level of probability. ${ }^{2} \pm$ Standard error of the mean

Source: Authors (2021)
}

\subsection{Economic feasibility}

According to a price survey (Sigma-Aldrich) performed in December 2017, rosmarinic acid is noteworthy for the value obtained when plant material is cultivated in the dark, reaching a gross value of U\$343.87/flask (Figure 9). However, losses can occur during the extraction process; thus, values vary based on the purification process. New studies to validate this process and additional market research are necessary to meet the demand for this bioactive substance. 
Figure 9. An estimate of the values generated per flask for caffeic acid, chlorogenic acid, rosmarinic acid, and luteolin produced via H. marrubioides callus cultivated under different spectral qualities (white light, blue light, red light, and blue + red light) and under darkness.

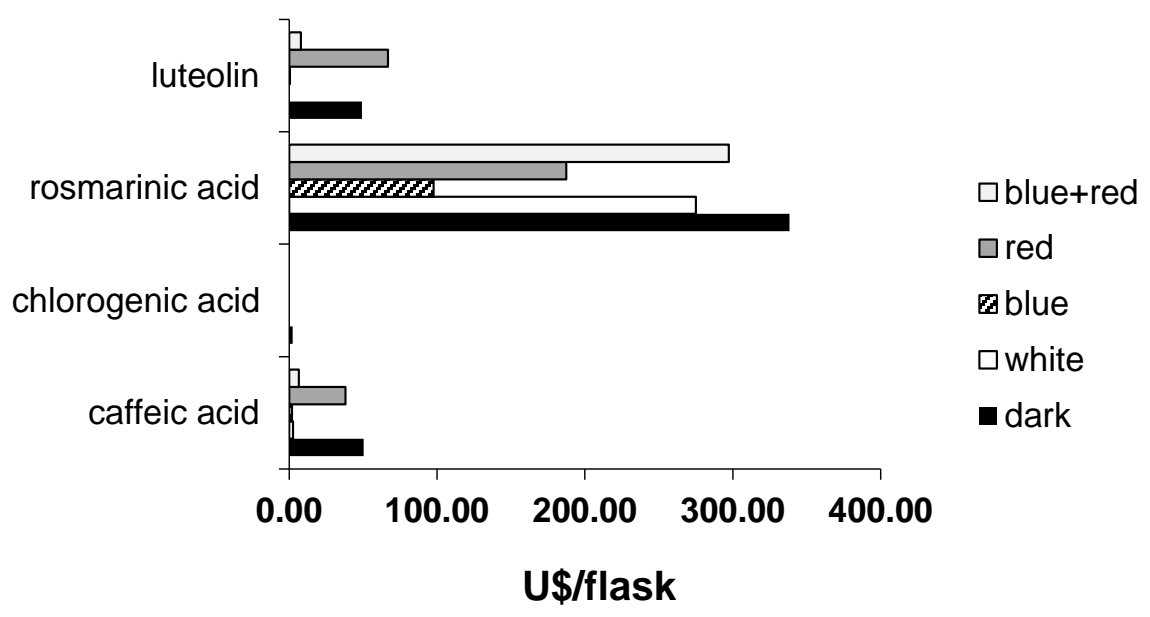

Source: Authors (2021).

Regarding the production of rosmarinic acid, exposure to UVC radiation resulted in less profit than biosynthesis under darkness (Figure 10).

Figure 10. An estimate of the values generated per flask for caffeic acid, chlorogenic acid, rosmarinic acid, and luteolin produced via $H$. marrubioides callus without exposure to UVC as well as 24 and 48 hours after UVC.

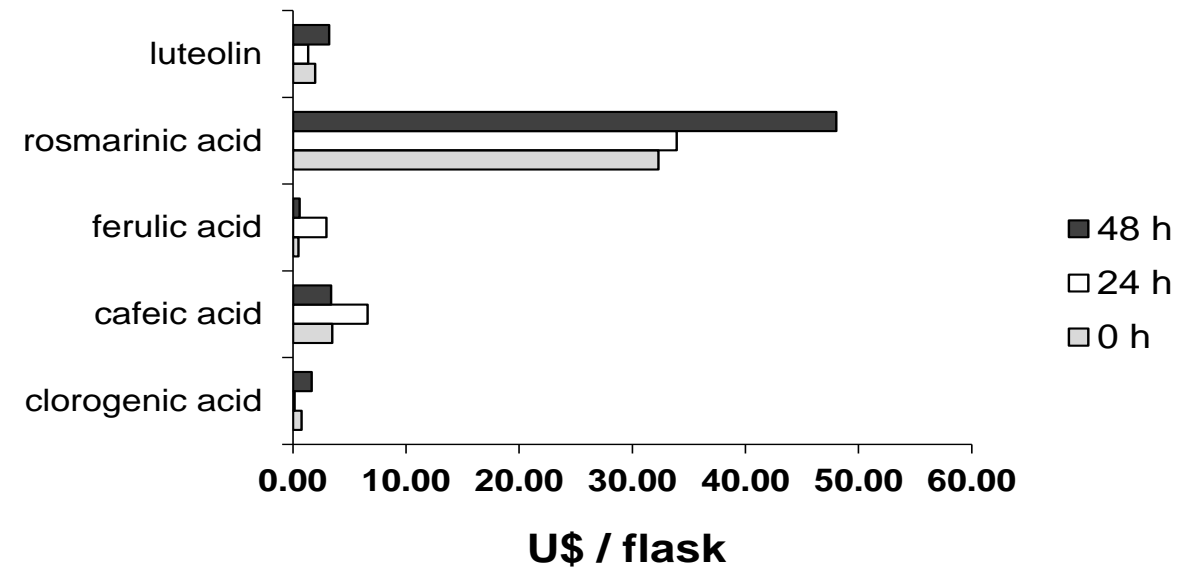

Source: Authors (2021).

In terms of economic feasibility, in vitro cultures possess the tools to optimize the production of bioactive metabolites and chemical compounds to obtain a sustainable and profitable production. Biotic and abiotic factors are used to improve 
productivity as well as to elucidate the physiological responses to stressor at the molecular level (Ramakrishna and Ravishankar, 2011).

\section{Discussion}

\subsection{Exposure to different spectral ranges}

Morphological variations were also observed in Artemisia absinthium L. callus cultivated under different spectral ranges (Tariq et al., 2014). The results in the literature are divergent, perhaps because of the differences regarding the behavioral and biochemical responses of the species. This result is also due to the different qualities and intensities of light that promote divergences regarding the morphological aspects of each cultivated callus and the particular physiological response for each species.

The callus of Carica papaya L. showed higher growth when cultivated in darkness. This finding suggests that both the callogenesis and biomass accumulation in callus vary according to the environment in which they are placed (Almeida, 2001).

A study of Artemisia absinthium L. showed a positive effect on induction and proliferation, regardless of the spectrum to which the callus were exposed; furthermore, several light qualities can help improve in vitro growth and production (Tariq et al., 2014). The use of different light qualities was demonstrated to be an important strategy in the production of biomass and bioactive compounds in Stevia rebaudiana Bert. (Ahmad et al., 2016), for which the cultivation of callus showed a higher accumulation of biomass under white light. However, the results of this experiment with $H$. marrubioides revealed that the production of the dry biomass in callus cultivated under white light did not show differences under different wavelengths.

Plants produce diverse metabolic responses after different biotic and abiotic stressors. White light and green light represent physical factors that positively affect the callogenesis of Artemisia absinthium L., whereas white light and red light increase the content of phenolic compounds (Tariq et al., 2014).

The biosynthesis rate of chlorogenic acid showed a better performance regarding $H$. marrubioides callus under darkness compared with the results of the radicular hairs of Echinacea purpurea Moench, which showed a better performance under lit conditions (Abassi et al., 2007). The accumulation of this compound might be correlated with the increase in the activity of the enzyme phenylalanine ammonia-lyase (PAL) when callus are cultivated under light. This enzyme is responsible for the initiation of the phenylpropanoid pathway in response to a variety of biotic and abiotic stresses (e.g., light) (Yousefzadi et al., 2012). The coordination of enzymatic activity as well as the production and biosynthesis of these secondary compounds are highly variable and genotype-dependent.

Of the metabolites with the highest contents detected, darkness had a considerable effect on the yield of caffeic acid, chlorogenic acid, rosmarinic acid, and luteolin. In the cell suspension culture of Thevetia peruviana, light quality affected the production of phenolic compounds, which is similar to the metabolites previously described. Cells that grew in darkness showed greater antioxidant activity than cultures exposed to light. An inhibitory effect on the production of phenolic compounds might have occurred in the presence of light because the gene expression involved in the biosynthesis of phenolic compounds was attenuated (Arias et al., 2016).

\subsection{Exposure to UVC radiation}

Exposure to UV radiation exerts a powerful stress on plants. Plant tissues respond to this stimulus by producing reactive oxygen species, which can cause peroxidation and the loss of cell membrane integrity, enzymatic inactivation, and 
damage to the structure of nucleic acids (Urban et al., 2016). In callus cultures, this effect can be observed as a decrease in growth and differential metabolic modulation (Zagoskina et al., 2003).

Zagoskina et al. (2005) observed the inhibitor effect of UVB radiation on the growth of the callus culture of Camellia sinensis, with a decrease in the size of callus-forming cells, possibly because of the long periods of UVB radiation that inhibit the process of cell elongation instead of mass growth, thereby resulting in less water content and modifications to certain morphological characteristics. By contrast, El-Aal and colleagues (El-Aal et al., 2016) observed that UVC radiation positively effects the biomass accumulation of callus and the cell suspension of Echinacea purpurea, with a significant increase in all growth parameters compared with the control. This positive effect might be because the additional capacity of UVC radiation, when applied for short periods of time, modulates defense mechanisms such as the increase in the activity of PAL, a key enzyme of the phenylpropanoid pathway and the antioxidant system. Although UVC radiation did not increase the levels of PAL transcripts in tomato plants (Tiecher et al., 2013), its activity is most likely induced at the post-transcriptional level (Urban et al., 2016).

The higher accumulation of the phenolic compounds observed in the current study is consistent with the responses observed in Catharanthus roseus L. callus (Moon et al., 2017), in which the total content of flavonoids and phenolic compounds were higher in the samples exposed to UVC compared with a control condition. Other authors have reported that the total content of flavonoids and phenolic compounds were positively affected by UVC radiation regarding Vitis vinifera L. callus (Cetin, 2014).

The time elapsed between the elicitation with UVC radiation and the collection of plant material was an important factor to maximize the potential to explore the metabolites observed regarding the synthesis of chlorogenic acid, caffeic acid, ferulic acid, rosmarinic acid, and luteolin in this study. The callus of Vitis vinifera L. showed the highest synthesis of stilbenes 48 hours after stimulation (Liu et al., 2010). However, Cetin (2014) worked with the same species and observed the highest accumulation of total phenolic compounds in plant material exposed to UVC for 5 minutes and analyzed 24 hours after exposure. In Echinacea purpurea callus, the derivatives of caffeic acid occurred in maximum concentrations 24 hours after stimulation, whereas phenolic compounds occurred in maximum concentrations 48 hours after exposure (El-Aal et al., 2016). Other reports have indicated that the effect of UVB radiation stimulates the accumulation of caffeic acid and rosmarinic acid in the leaves of Rosmarinus officinalis L. (Luis et al, 2007).

UV radiation seems to act primarily on the synthesis of phenolic compounds, considering that this metabolic class plays an important role in overcoming oxidative stress. Therefore, the cell capacity for the formation of phenolic compounds is directly related to its resistance to UV radiation (Dias et al., 2016; Huché-Thélier et al., 2016).

UV radiation is divided into UVA $(315-400 \mathrm{~nm})$, UVB $(280-315 \mathrm{~nm})$, and UVC (100-280 nm) based on its wave and particle behavior. This radiation exerts important effects on many biomacromolecules including DNA, RNA, lipids, and proteins (Gupta et al., 2017). Plants are primarily affected by UVA and UVB (wavelengths that cross the ozone layer and reach the Earth's surface), whereas UVC is barred by this protective layer of gas. However, with the ever decreasing ozone layer due to anthropic action, this more harmful radiation reaches the Earth's surface with greater frequency, thereby affecting various organisms (Huché-Thélier et al., 2016; Gupta et al., 2017).

Exposing a plant to UV radiation for short periods of time might stimulate the plant's defenses, thereby generating new compounds or increasing the synthesis of other compounds with biological and pharmacological properties (Dias et al, 2016; Marti et al, 2014). However, prolonged exposure is considered a cause of severe stress that damages DNA, resulting in the inhibition of photosynthesis and increases in phenolic compounds (Kravets et al., 2013; Wargent and Jordan, 2013). 
The trend of new research projects focused on the metabolic engineering of plants provides a promising future regarding other biotechnological fields. However, information on biosynthesis pathways remains insufficient. The application of biosynthesis pathways focused on bioactive compounds of pharmacological interest leads to the investigation of new pathways, with success primarily in the alkaloid pathway, and shows potential use for other groups of secondary metabolites (Bourgaud et al., 2001).

\subsection{Economic feasibility}

The trend of new research projects focused on the metabolic engineering of plants provides a promising future regarding other biotechnological fields. However, information on biosynthesis pathways remains insufficient. The application of biosynthesis pathways focused on bioactive compounds of pharmacological interest leads to the investigation of new pathways, with success primarily in the alkaloid pathway, and shows potential use for other groups of secondary metabolites (Bourgaud et al., 2001).

\section{Conclusion}

The exposure of H. marrubioides callus to blue light negatively affects the synthesis of phenolic compounds. Red light stimulates the synthesis of caffeic acid and luteolin. Darkness was the best condition among those studied because it was associated with the increased accumulation of caffeic acid, chlorogenic acid, rosmarinic acid, and luteolin.

The exposure of $H$. marrubioides callus cultivated under white light to UVC radiation promoted an increase in the synthesis of chlorogenic acid, ferulic acid, rosmarinic acid, and luteolin. Future studies involving greater light intensity or different times of exposure to ultraviolet radiation in the culture environment may complement studies on calluses of $\mathrm{H}$. marrubioides, to verify changes in the accumulation of bioactives.

Acknowledgements: We acknowledge the Pró Centro-Oeste Network, and the Federal Institute of Education, Science and Technology Goiano (IF Goiano) for their support; The Brazilian Federal Agency for the Support and Evaluation of Graduate Education (CAPES), and the Research Foundation of Goiás (FAPEG).

Declarations of interest: The authors declare that they have no conflict of interests.

\section{References}

Abbasi, B.H., Tian, C.L., Murch, S.J., Saxena, P.K., \& Liu, C.Z. (2007). Light-enhanced caffeic acid derivatives biosynthesis in hairy root cultures of Echinacea purpurea, Plant Cell Reports, 26, 1367-1372. https://doi.org/10.1007/s00299-007-0344-5.

Abd El-Aal, M.S., Rabie K.A.E., \& Manaf, H.H. (2016). The effect of uv-c on secondary metabolites production of echinacea purpurea culture in vitro, J. Biol. Chem. Environ. Sci., 11, 465-483.

Ahmad, N., Rab A., \& Ahmad, N. (2016). Light-induced biochemical variations in secondary metabolite production and antioxidant activity in callus cultures of Stevia rebaudiana (Bert), Journal of Photochemistry and Photobiology B, 154, 51-56. https://doi.org/10.1016/j.jphotobiol.2015.11.015.

Almeida E.P., R.P. Oliveira, \& Dantas J.L.L. (2001). Indução e desenvolvimento de calos e embriões somáticos em mamoeiro, Scientia Agricola, 58, 51-54. http://dx.doi.org/10.1590/S0103-90162001000100009.

Arias, J.P., Zapata K., Rojano, B., \& Arias, M. (2016). Effect of light wavelength on cell growth, content of phenolic compounds and antioxidant activity in cell suspension cultures of Thevetia peruviana, Journal of Photochemistry and Photobiology B, 163, 87-91. http://dx.doi.org/10.1016/j.jphotobiol.2016.08.014. 
Arrigoni-Blank, M.F., Antoniolli, A.R., Caetano, L.C., Campos, D.A., Blank, A.F., \& Alves, P.B. (2008). Antinociceptive activity of the volatile oils of Hyptis pectinata L. Poit. (Lamiaceae) genotypes, Phytomedicine, 15, 334-339. https://doi.org/10.1016/j.phymed.2007.09.009.

Barbosa, P.P.P., \& Ramos C.P. (1992). Studies on the antiulcerogenic activity of the essential oil ofHyptis mutabilis Briq. in Rats, Phytotherapy Research, 6, 114-115. https://doi.org/10.1002/ptr.2650060214.

Bourgaud, F., Gravot, A., Milesi, S., \& Gontier, E. (2001). Production of plant secondary metabolites: a historical perspective, Plant Science, $2001,839-851$. https://doi.org/10.1016/S0168-9452(01)00490-3.

Bueno, A.X., Moreira, A.T.S., \& Silva, F.T. (2006). Estevam, C.S., Marchioro, M., Effects of the aqueous extract from Hyptis pectinata leaves on rodent central nervous system, Revista Brasileira de Farmacognosia, 16, 317-323. https://doi.org/10.1590/S0102-695X2006000300007.

Carvalho, S.D., \& Folta, K.M. (2014). Sequential light programs shape kale (Brassica napus) sprout appearance and alter metabolic and nutrient content, Horticulture Research, 1, 1-13. http://dx.doi.org/10.1038/hortres.2014.8.

Cetin, E.S. (2014). Induction of secondary metabolite production by UV-C radiation in Vitis vinifera L. Öküzgözü callus cultures, Biological Research, $47,37$. https://doi.org/10.1186/0717-6287-47-37.

Coelho, G.C., Rachwal, M.F.G., Dedecek, R.A., Curcio, G.R., Nietsche, K., \& Schenkel, E.P. (2007). Effect of light intensity on methylxanthine contents of Ilex paraguariensis A. St. Hil, Biochemical Systematics and Ecology, 35, 75-80. https://doi.org/10.1016/j.bse.2006.09.001.

Costa, J.G.M., Rodrigues, F.F.G., Angélico, E.C., Silva, M.R., Mota, M.L., Santos, N.K.A., Cardoso, A.L.H., \& Lemos, T.L.G. (2005). Estudo químicobiológico dos óleos essenciais de Hyptis martiusii, Lippia sidoides e Syzigium aromaticum frente às larvas do Aedes aegypti, Revista Brasileira de Farmacognosia, 15. https://doi.org/10.1590/S0102-695X2005000400008.

Coutinho, H.D.M., Costa, J.G.M., Lima, E.O., Falcão-Silva, V.S.,. \& Siqueira-Júnior, J.P. (2009). In vitro interference of Hyptis martiusii Benth. \& chlorpromazine against an aminoglycoside - resistant Escherichia coli, The Indian Journal of Medical Research, 129, 566-568.

Dias, M.I., Sousa, M.J., Alves, R.C., \& Ferreira, I.C.F.R. (2016). Exploring plant tissue culture to improve the production of phenolic compounds: a review. Industrial Crops and Products, 82, 9-22. https://doi.org/10.1016/j.indcrop.2015.12.016.

Fazal, H., Abbasi, B.H., Ahmad, N., Ali, S.S., Akbar, F., \& Kanwal, F. (2016). Correlation of different spectral lights with biomass accumulation and production of antioxidant secondary metabolites in callus cultures of medicinally important Prunella vulgaris L, Journal of Photochemistry and Photobiology B, 159, 1-7. https://doi.org/10.1016/j.jphotobiol.2016.03.008.

Ferreira, D.F., (2011) SISVAR: a computer statistical analysis system, Ciência e Agrotecnologia, 35, 1039-1042. http://dx.doi.org/10.1590/S141370542011000600001

Gupta, S.K., Sharma, M., Deeba, F., \& Pandey, V. (2017). Plant Response: UV-B Avoidance Mechanisms, in: V.P. Singh, S. Singh, S.M. Prasad, P. Parihar (Eds.) UV-B radiation: from environmental stressor to regulator of plant growth, Wiley Blackwell, Chichester, pp. 227-258.

Hernandez-Aguilar, C., Dominguez-Pacheco, A., Tenango, M. P., Valderrama-Bravo, C., Hernández, M. S., Cruz-Orea, A., \& Ordonez-Miranda, J. (2021). Characterization of bean seeds, germination, and phenolic compounds of seedlings by UV-C radiation. Journal of Plant Growth Regulation, 40(2), 642-655. https://doi.org/10.1007/s00344-020-10125-0.

Huché-Thélier, L., Crespel, L., Gourrierec, J.L., Morel, P., Sakr, S., \& Leduc, N. (2016). Light signaling and plant responses to blue and UV radiationsPerspectives for applications in horticulture. Environmental and Experimental Botany, 121, 22-38. https://doi.org/10.1016/j.envexpbot.2015.06.009.

Kokotkiewicz, A., Bucinski, A., \& Luczkiewicz M. (2014). Light and temperature conditions affect bioflavonoid accumulation in callus cultures of Cyclopia subternata Vogel (honeybush), Plant Cell Tissue Organ Cult, 118, 589-593. https://doi.org/10.1007/s11240-014-0502-8.

Kravets, A.P., Sokolova, D.A., Vengzhen, G.S., \& Grodzinskiǐ, D.M. (2013). [Fractionated UV-C irradiation effects on the changes of transcribed and satellite DNA methylation profile and unstable chromosomal aberration yield], Radiation biology, radioecology, 53, 583-591.

Kuhnt, M., Probstle, A., Rimpler, H., Bauer, R., \& Heinrich, M. (1995). Biological and pharmacological activities and further constituents of Hyptis verticillata, Planta Medica, 61, 227-232. https://doi.org/10.1055/s-2006-958061.

Liu, W., Liu, C., Yang, C., Wang, L., \& Li, S. (2010). Effect of grape genotype and tissue type on callus growth and production of resveratrols and their piceids after UV-C irradiation, Food Chemistry, 122, 475-481.

Liu, Z., Zhang, Y., Wang, J., Li, P., Zhao, C., Chen, Y., \& Bi, Y. (2015). Phytochrome-interacting factors PIF4 and PIF5 negatively regulate anthocyanin biosynthesis under red light in Arabidopsis seedlings, Plant Science, 238, 64-72. https://doi.org/10.1016/j.plantsci.2015.06.001.

Luis, J.C., Pérez, R.M., \& González, F.V. (2007). UV-B radiation effects on foliar concentrations of rosmarinic and carnosic acids in rosemary plants, Food Chemistry, 101, 1211-1215. https://doi.org/10.1016/j.foodchem.2006.03.023.

Marti, G., Schnee, S., Andrey, Y., Simoes-Pires, C., Carrupt, P.A., Wolfender, J.L., \& Gindro, K. (2014). Study of leaf metabolome modifications induced by UV-C radiations in representative Vitis, Cissus and Cannabis species by LC-MS based metabolomics and antioxidant assays, Molecules, 19, 14004-14021. https://doi.org/10.3390/molecules190914004.

Moon, S.H., Mistry, B., Kim, D.H., \& Pandurangan, M. (2017). Antioxidant and anticancer potential of bioactive compounds following UV-C light-induced plant cambium meristematic cell cultures. Industrial Crops and Products, 109, 762-772. https://doi.org/10.1016/j.indcrop.2017.09.024.

Murashige, T., \& Skoog, F. (1962). A revised medium for rapid growth and bioassays with tobacco tissue cultures, Physiology Plant, 15, 473-497. https://doi.org/10.1111/j.1399-3054.1962.tb08052.x. 
Research, Society and Development, v. 10, n. 9, e59210918472, 2021 (CC BY 4.0) | ISSN 2525-3409 | DOI: http://dx.doi.org/10.33448/rsd-v10i9.18472

Murthy, H.N., Lee, E.J., \& Paek, K.Y. (2014). Production of secondary metabolites from cell and organ cultures: strategies and approaches for biomass improvement and metabolite accumulation, Plant Cell Tissue Organ Cult, 118, 1-16. https://doi.org/10.1007/s11240-014-0467-7.

Pereira, A. S., Shitsuka, D. M., Parreira, F. J., \& Shitsuka, R. (2018). Metodologia da Pesquisa científica. [e-book]. Santa Maria. Ed. UAB/NTE/UFSM. Disponível em: https://repositorio.ufsm.br/bitstream/handle/1/15824/Lic_Computacao_Metodologia-Pesquisa-Cientifica.pdf?sequence=1. Acesso em: 25 Julho 2021

Ramakrishna, A., \& Ravishankar, G.A. (2011). Influence of abiotic stress signals on secondary metabolites in plants, Plant Signaling \& Behavior, 6, 17201731. https://doi.org/10.4161/psb.6.11.17613.

Rodrigues, V.E.G., \& Carvalho, D.A.D. (2001). Levantamento etnobotânico de plantas medicinais no domíniodo cerrado na região do alto rio Grande - Minas Gerais, Ciência e Agrotecnologia, 25, 102-123.

Tariq, U., Ali, M., \& Abbasi, B.H. (2014). Morphogenic and biochemical variations under different spectral lights in callus cultures of Artemisia absinthium L, Journal of Photochemistry and Photobiology B, 130, 264-271. http://dx.doi.org/10.1016/j.jphotobiol.2013.11.026.

Tiecher, A., de Paula, L.A., Chaves, F.C., \& Rombaldi, C.V. (2013). UV-C effect on ethylene, polyamines and the regulation of tomato fruit ripening, Postharvest Biology Technology, 86, 230-239. https://doi.org/10.1016/j.postharvbio.2013.07.016

Urban, L., Charles, F., de Miranda, M.R.A., \& Aarrouf, J. (2016). Understanding the physiological effects of UV-C light and exploiting its agronomic potential before and after harvest, Plant Physiology and Biochemistry, 105, 1-11. https://doi.org/10.1016/j.plaphy.2016.04.004

Villacís-Chiriboga, J., Elst, K., Van Camp, J., Vera, E., \& Ruales, J. (2020). Valorization of byproducts from tropical fruits: Extraction methodologies, applications, environmental, and economic assessment: A review (Part 1: General overview of the byproducts, traditional biorefinery practices, and possible applications). Comprehensive Reviews in Food Science and Food Safety, 19(2), 405-447. https://doi.org/10.1111/1541-4337.12542.

Wang, H., Ma, L.G., Li, J.M., Zhao, H.Y., \& Deng, X.W. (2001). Direct interaction of Arabidopsis cryptochromes with COP1 in light control development, Science, 294, 154-158, https://doi.org/10.1126/science.1063630.

Wargent, J.J., \& Jordan, B.R. (2013). From ozone depletion to agriculture: understanding the role of UV radiation in sustainable crop production, New Phytologist, 197, 1058-107. https://doi.org/10.1111/nph.12132.

Yousefzadi, M., Sharifi, M., Behmanesh, M., Ghasempour, A., Moyano, E., \& Palazon, J. (2012). The effect of light on gene expression and podophyllotoxin biosynthesis in Linum album cell culture, Plant Physiology and Biochemistry, 56, 41-46. https://doi.org/10.1016/j.plaphy.2012.04.010.

Zagoskina, N.V., Alyavina, A.K., Gladyshko, T.O., Lapshin, P.V., Egorova, E.A., \& Bukhov, N.G. (2005). Ultraviolet rays promote development of photosystem II photochemical activity and accumulation of phenolic compounds in the tea callus culture (Camellia sinensis), Russian Journal of Plant Physiology, 52, 731-739. https://doi.org/10.1007/s11183-005-0109-3.

Zagoskina, N.V., Dubravina, G.A., Alyavina, A.K., \& Goncharuk, E.A. (2003). Effect of ultraviolet (UV-B) radiation on the formation and localization of phenolic compounds in tea plant callus cultures, Russian Journal of Plant Physiology, 50, 270-275. https://doi.org/10.1023/A:1022945819389. 